\title{
Genetic Mechanism of the Dolomite in Dolomitic Glutenite of the Shahejie Formation-A Case Study of QHD 29-2 Oilfield in Bohai Bay Basin, China
}

\author{
Liya Da, Deying Wang, Haibo Yu, Jianmin Zhu \\ Tianjin Branch, CNOOC China Limited, Tianjin, China \\ Email: zhujm3@cnooc.com.cn
}

How to cite this paper: Da, L.D., Wang, D.Y., Yu, H.B. and Zhu, J.M. (2019) Genetic Mechanism of the Dolomite in Dolomitic Glutenite of the Shahejie Formation-A Case Study of QHD 29-2 Oilfield in Bohai Bay Basin, China. Open Journal of Geology, 9, 461-473.

https://doi.org/10.4236/ojg.2019.98030

Received: July 24, 2019

Accepted: August 27, 2019

Published: August 30, 2019

Copyright $\odot 2019$ by author(s) and Scientific Research Publishing Inc. This work is licensed under the Creative Commons Attribution International License (CC BY 4.0).

http://creativecommons.org/licenses/by/4.0/

\begin{abstract}
The dolomite in dolomitic glutenite of the shahejie formation in the eastern steep slope of the Shijiutuo bulge in Bohai is a high-quality reservoir, and the content of dolomite is positively correlated with reservoir physical properties. In this paper, by using thin section, core, wall core, geochemical data and analyzing petrology and mineralogy characteristic, we systematically analyzed the paleogeographic environment and genetic mechanism of this kind of dolomite and established the genetic models. The dolomite in the glutenite body has many characteristics of development, which is formed by three kinds of genesis: quasi-synergy dolomitization, buried dolomitization and hydrothermal dolomitization. The dolomite in glutenite is produced in the form of matrix, grain (sandstone, oolith), biological skeleton (conch, ostracod), clastic shell and dolomite cement. The minor elements, carbon and oxygen isotopes, trace minerals and paleontological combinations reveal that the paleogeographic environment was closed continental salt-brackish water bay, the climate was arid and hot, and the evaporation was strong. It provides favorable conditions for the production of the dolomite in dolomitic glutenite. There are three genetic models of dolomite. The first model is penecontemporaneous dolomitization. The climate was arid and hot, the aragonite and high-magnesium calcite deposited with sand and gravel. Due to the effect of evaporation, dolomitization occurred. The second model is buried dolomitization. The water from dehydration of clay minerals causes the $\mathrm{Mg}^{2+}$ in the high-magnesium formation migrating into the rock, leading to the occurrence of dolomitization. The third model is hydrothermal dolomitization. Deep faults can bring geothermal fluids into the overlying reservoir and form the hydrothermal dolomite.
\end{abstract}




\section{Keywords}

Genetic Mechanism of the Dolomite, Dolomitic Glutenite, Shahejie

Formation, Eastern Steep Slope of Shijiutuo Bulge, Bohai Bay Basin

\section{Introduction}

Dolomite as a good reservoir in carbonate rocks is an important target of oil and gas exploration. A large number of marine dolomite reservoirs are developed in the Sichuan Basin, the Tarim Basin, and the Ordos Basin [1] [2]. The lacustrine dolomite in the continental formation such as Dongying sag, Junggar Basin, Santanghu Basin, Qikou sag and Bozhong sag is also widely developed [3] [4] [5] [6]. In recent years, the dolomitic glutenite reservoir with high oil production was discovered in the Shahejie formation of the eastern steep slope of the Shijiutuo bulge in the Bohai Sea. For the lacustrine dolomite reservoir characteristics, diagenesis, paleogeographic environment and control factors, many research findings have been carried out by the predecessors. However, the research on the genetic mechanism of dolomite in the dolomitic glutenite is lacking, especially in the Bohai Sea. In this paper, the dolomitic glutenite of the Shahejie formation in the eastern steep slope of the Shijiutuo bulge is the main research object. The petrology and mineralogy analysis, the formation and sedimentary environment of dolomite, and the genetic model are established. It has guiding significance for the study of the genesis of dolomite in lacustrine carbonate reservoir.

\section{Structure and Sedimentary Background}

The eastern part of the Shijiutuo bulge is located in the western of the Bohai Sea, the west side is connected with the main area of the Shijiutuo bulge, and the north and south sides are respectively connected with the Bozhong sag and the Qinnan sag, and disappeared to the east in the Bozhong sag. It is a favorable position for oil and gas migration and accumulation (Figure 1). The Bohai Bay Basin

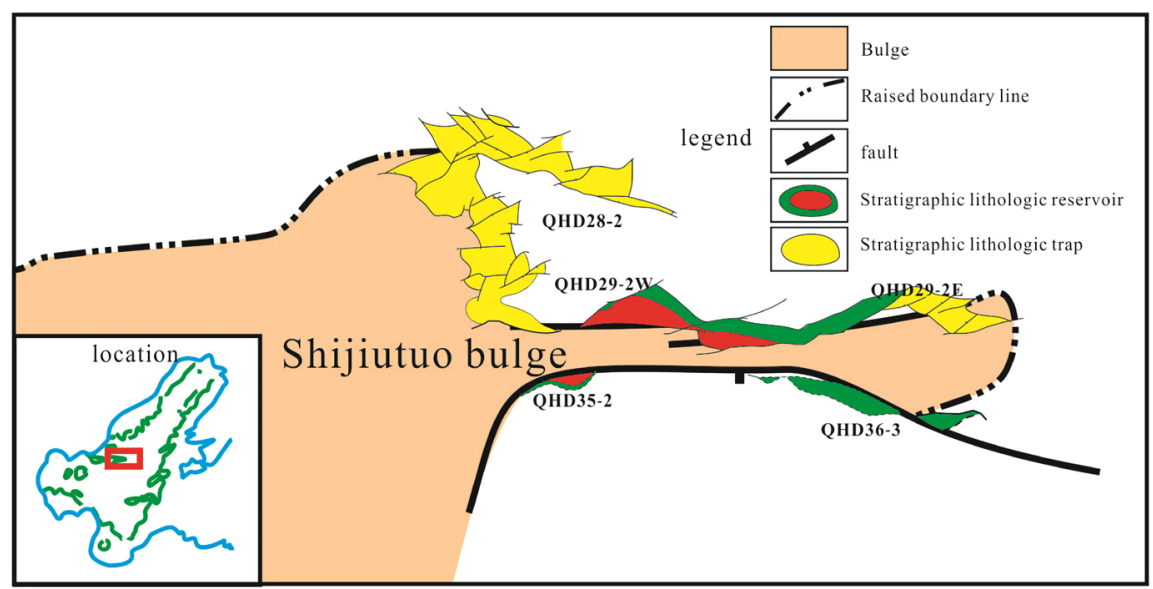

Figure 1. QHD29-2 oilfield location map. 
was a typical pull-apart basin that was formed in the late Mesozoic to early Paleogene period. At that time, the eastern part of the Shijiutuo bulge mainly developed the east-west direction basal extensional fault. During the Paleogene period, the area was mainly affected by the mantle heat flow, and the regional extension occurred. At this time, it was an extensional fault basin [7], the north and south boundary faults of the bulge continue to develop. The biologically-rich dolomitic glutenite of the Shahejie formation in thrown side is the fan delta frontier deposit developed in the background of the extensional fault basin. The lithology of the fan delta is mainly composed of glutenite, pebbly sandstone, sandstone, etc, and bioclastics such as ostracods and snail fossils are deposited between glutenite particles, forming a new type of "bio-rich" fan delta deposit. The observation of thin slices shows that the dolomite ring is generally around the gravel, and the bioclastic component is mainly dolomite. When the burial depth is greater than $3500 \mathrm{~m}$, the porosity of the reservoir is more than $10 \%$, and the highest is up to $30 \%$. Tested in this special fan delta reservoir to obtain 1000 tons oil of daily output, it is an important reservoir of QHD 29-2 oilfield.

\section{Petrology and Mineralogy Characteristics of Dolomite}

The petrology types of the Shahejie formation of the study area are complex, the composition is dominated by glutenite, and a large number of carbonates are developed. clastic constituents are mainly feldspar, quartz, lithic fragment and carbonate. Bioclastics develop in large numbers, showing conchs and Ostracods, etc. The reservoir contains a large amount of dolomite. The variation of dolomite content is mainly between $25 \%$ and $82 \%$, and the reservoir with less than $50 \%$ dolomite content is rare, it is a typical dolomitic rock [8]. The set of dolomitic rock is different from marine carbonate rock, which is complicated by the influence of land supply.

Dolomite is produced in the form of matrix, grain (sandstone, oolith), biological skeleton (conch, ostracod), clastic shell and dolomite cement. The dolomite production in the matrix form is more common in the grain dolomite, and the dolomite cement is more common and easy to found in the dolomitic glutenite.

1) Dolomite matrix

Dolomite crystal size ranges between cryptocrystalline (unrecognized by polarized light microscopy) to microcrystals (single crystal particles can be identified by polarized light microscopy). The recrystallization of the matrix is not obvious, there is no obvious texture structure, and the shale content is small (Figure 2(a)).

2) Dolomitic grained clasts

Dolomitic grained clasts are mostly produced in grained dolomite, and the rock has a microcrystalline sand-clastic structure and a massive structure. The content of grain is $>50 \%$, and the appearance of grain is round, sub-circular, elliptical, and the sorting is good-medium. The grain is sand-clastic cryptocrystalline dolomite chips and oolith cryptocrystalline dolomite chips, and the inner 

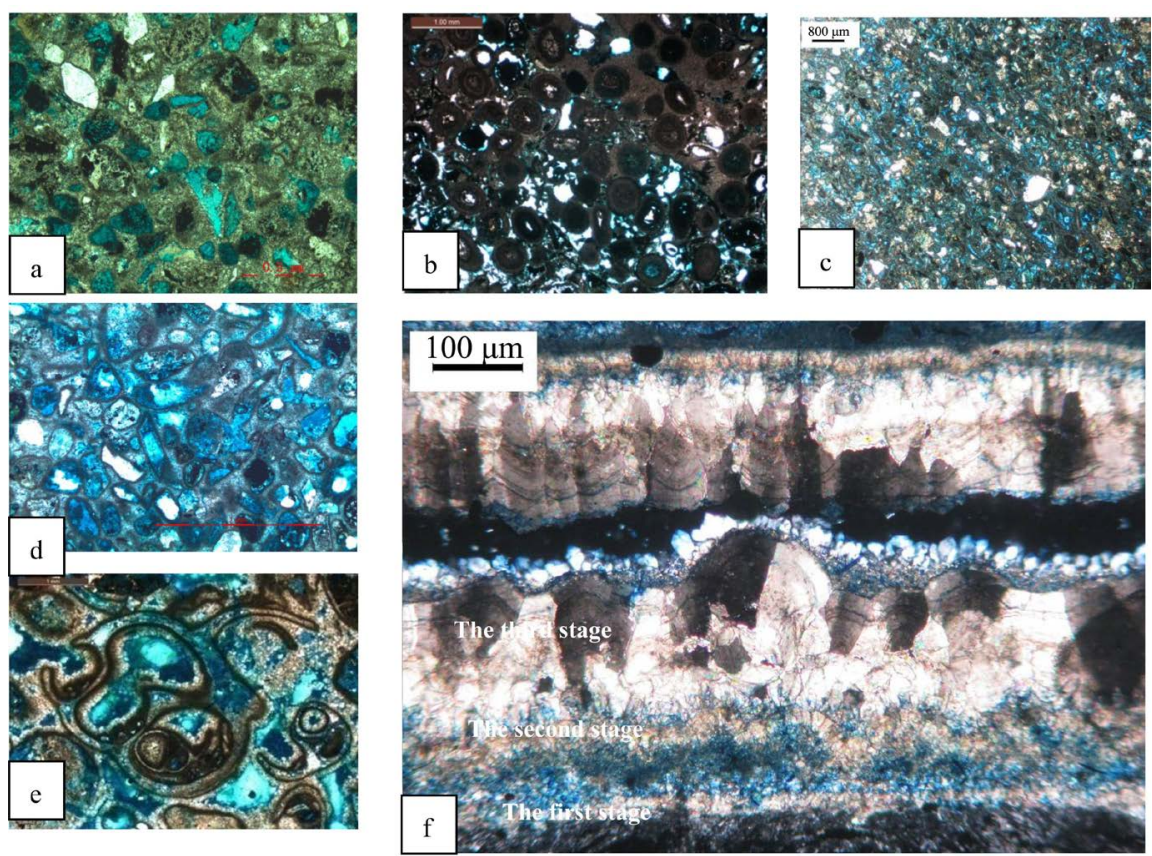

Figure 2. Petrology and mineral characteristics of dolomitic glutenite. (a) QHD29-2E-A well, $\mathrm{E}_{3} \mathrm{~s}^{1-2}$, Grained clastsdolomitic, cross-polarized light, 25x. (b) QHD29-2E-A well, $\mathrm{E}_{3} \mathrm{~s}^{1-2}$, The cryptocrystalline oolith dolomite, grained clastsstructure, The grained clasts component is mainly oolithes, which size is $0.25-0.50 \mathrm{~mm}$, and heart is dissolved and filled with a small amount of secondary kaolinite. plane-polarized light, 12.5x. (c) QHD29-2E-A well, $\mathrm{E}_{3} \mathrm{~s}^{1-2}$, Sand-bearing grained clasts dolomitic, the grained clasts composition includes dolomite sand-clastic and Ostracod, the sandclastic content is $<10 \%$, the ostracod is oriented, plane-polarized light, 12.5x. (d) QHD29-2E-A well, E s $^{1-2}$, biological clasts dolomite, conchs content $>50 \%$, the organism is relatively well preserved, the body cavity is developed, plane-polarized light, 25x. (e) QHD29-2E-A well, $\mathrm{E}_{3} \mathrm{~s}^{1-2}$, conchs biofossil, plane-polarized light, 25x. (f) QHD29-2E-A well, $\mathrm{E}_{3} \mathrm{~s}^{1-2}$, The dolomite cement in the crack is cemented in three stages, cross-polarized light, $25 \mathrm{x}$.

layer structure of ooliths are clearly visible (Figure 2(b)). The relationship between particles and matrix are mostly particle support, and the interstitial is dolomite mud.

3) Dolomitic biological clasts skeleton

The biological clasts grains are mostly conchs and Ostracods (Figure 2(c)). The conchs were preserved well (Figure 2(d)), the biological skeleton is cryptocrystalline dolomite, and the pores of the organism develop. The Ostracod shell is about $0.03-1.00 \mathrm{~mm}$ thick.

4) Dolomitic cladding

Dolomite cladding is more common distributed in sandy dolomite. Its particle composition is mainly silt-grade quartz and volcanic rock clips. Quartz particles are mainly distributed in a single particle form in the dolomite matrix or in a stacked form. The terrigenous clastic particles have a cladding similar to the oolith shell, cryptocrystalline structure, no recrystallization, and crystal morphology is not recognized (Figure 2(e)). The thickness of the cladding is less than 0.01 $\mathrm{mm}$, and the thickness distribution is uniform. It can be seen by cathodolumi- 
nescence analysis that the luminescent color of dolomite cladding, dolomite matrix and dolomite particles are different, indicating that they were formed at different stage.

5) Dolomitic cement

Under the microscope, the dolomite cement in the glutenite has a typical multi-stage sublayer structure. The shape of the dolomite cement is isopachous ring, granular, horse-tooth, etc. The crystal size varies greatly, cryptocrystals, microcrystals, fine crystals, medium crystals and megacryst all appear. According to the morphology analysis of cement crystals, there are third-stage dolomite cements, which diagenetic environment mainly includes lake water undercurrent belt, shallow buried undercurrent belt and deep buried hydrothermal undercurrent belt [9]. The first stage is cryptocrystalline-microcrystalline dolomite, the second is the grainy powder crystal dolomite, and the third is the horse-tooth shape megacryst iron dolomite (Figure 2(f)). The first stage of dolomite cement shape is usually isopachous ring or fibrous, and is cemented around the edges of the particles. The crystal has a clear appearance and a clear boundary, and formed along the long axis perpendicular to the particle wall, and the diameter is $0.01-0.03 \mathrm{~mm}$. It indicates that the original composition of the first stage of fibrillar dolomite cement is magnesium calcite or aragonite and formed in the lake bottom undercurrent belt, and the dolomite cement is the product in the course of sedimentary. The second stage of fine-powdered isopachous dolomite cement grows along the first stage of fibrillar dolomite, and is generally idiomorphic, semi-idiomorphic crystal, and is a production of shallow burial period dolomitization. The third stage of the horse-tooth shape megacryst iron dolomite, with coarse crystals, idiomorphic and semi-idiomorphic crystal, with the diameter is $0.05-0.2 \mathrm{~mm}$. The stepped crystal lattice often found in iron dolomite planes.

\section{Dolomite Diagenetic Environment}

\subsection{Minor Element Characteristics}

The minor elements and geochemical characteristics of sedimentary rocks are affected by paleogeographic environment, including paleoclimate, ancient landform and ancient water properties. Therefore, minor elements of sedimentary rocks can be used as important indicators to analyze the paleoenvironment [10]. The trace element $\mathrm{V} / \mathrm{Ni}$ ratio is a good indicator for discriminating the sedimentary facies and sedimentary environment. The $\mathrm{V} / \mathrm{Ni}$ ratio of marine sediments is smaller than that of the terrestrial environment. It is generally considered that $\mathrm{V} / \mathrm{Ni}<1$ is a marine environment and $\mathrm{V} / \mathrm{Ni}>1$ is a terrestrial environment [11]. The $\mathrm{V} / \mathrm{Ni}$ ratio in the dolomitic clastic rocks in the study area is $3.94-1.78$, with an average of $2.63 \mathrm{ug} / \mathrm{g}$. The distribution of $\mathrm{U}$ and Th is closely related to the sedimentary environment. The abundance of $\mathrm{U}$ is higher in marine sediments, while Th is higher in terrestrial sediments. According to this, the $\mathrm{Th} / \mathrm{U}$ ratio can be used as an important indicator to distinguish sedimentary en- 
vironment. It is considered that $\mathrm{Th} / \mathrm{U}>6$ is the marine environment and $\mathrm{Th} / \mathrm{U}$ $<6$ is the terrestrial environment [5]. The Th/U ratio in the study area is $5.07-$ 0.81 , with an average of $2.63 \mathrm{ug} / \mathrm{g}$. In addition to reflecting the water salinity, the $\mathrm{Sr} / \mathrm{Ba}$ ratio can also be used to judge the sedimentary environment. It is generally considered that $\mathrm{Sr} / \mathrm{Ba}>1$ is the marine sedimentary environment and $\mathrm{Sr} / \mathrm{Ba}<$ 1 is the inland freshwater environment [12]. The study area $\mathrm{Sr} / \mathrm{Ba}<0.1$, is the terrestrial environment (Figure 3 ). The overall data analysis suggests that dolomitic glutenite is formed in terrestrial environment.

There are many trace elements in the sedimentary rocks. The changes of these elements are controlled by the difference of land water system supply and the paleoclimate. The lacustrine carbonate is mostly a product of high salinity and high $\mathrm{Ph}$ media deposition. Due to the geochemical instability of the lake, a large number of trace elements (such as B, Sr, P, Ba, Fe, Mn, etc.) can be used to distinguish the sedimentary environment, analyze the source and judge the paleoclimate [13]. The statistical analysis of trace element data shows that the Sr, B, and $\mathrm{P}$ elements in $\mathrm{E}_{3} \mathrm{~s}^{1-2}$ have a significant increase trend (Figure 4), which is
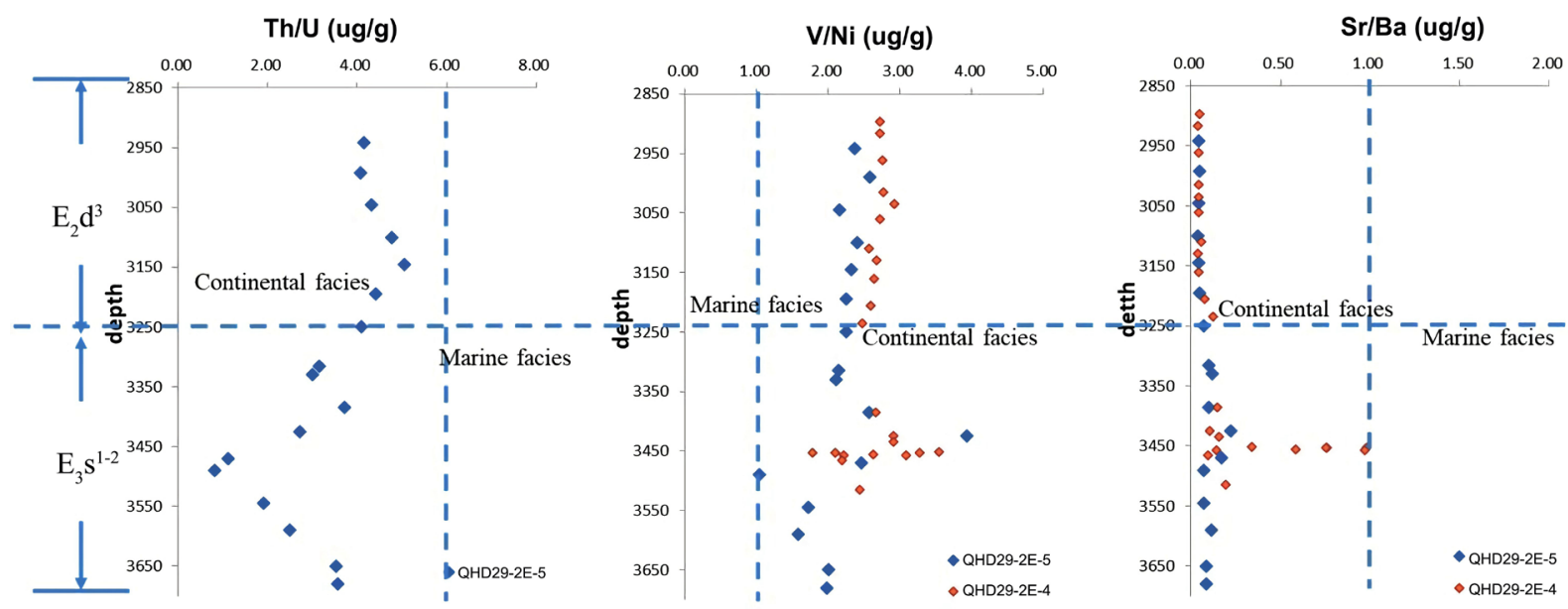

Figure 3. Minorelement distribution of dolomitic glutenite.
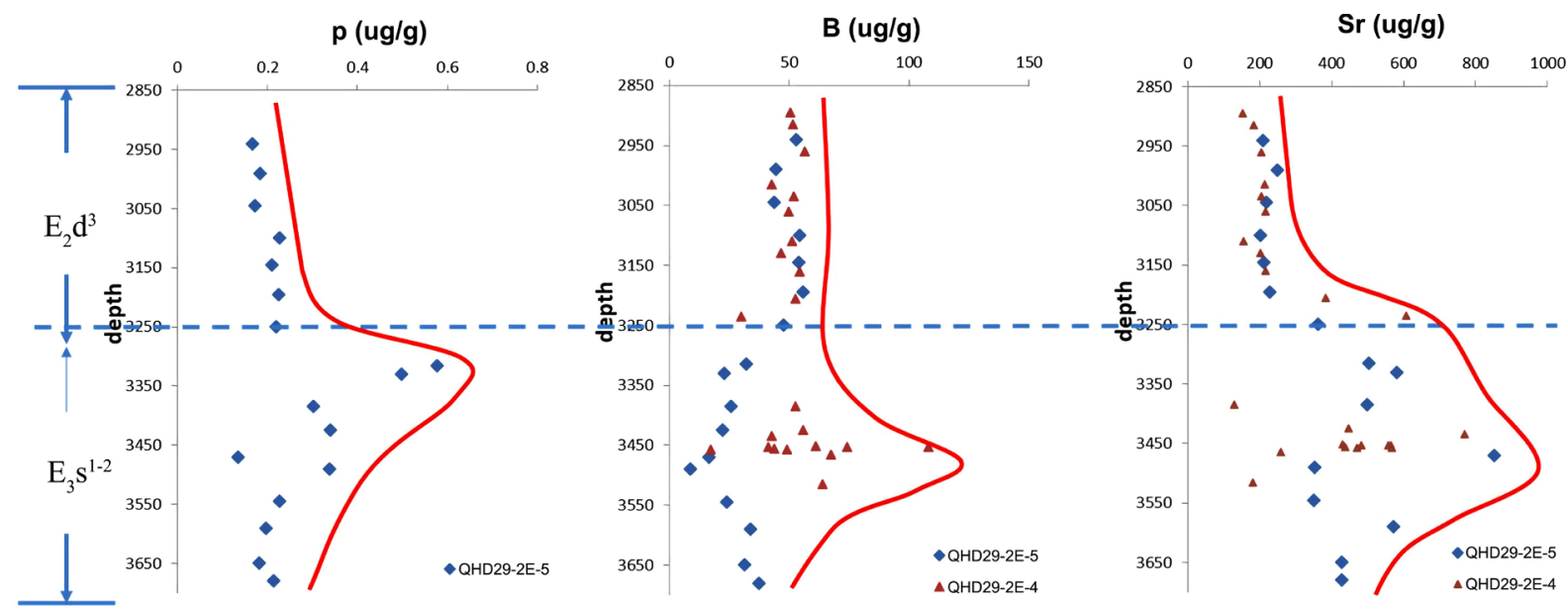

Figure 4. Trace element distribution of dolomitic glutenite. 
distinct from the freshwater sedimentary environment in $\mathrm{E}_{2} \mathrm{~d}^{3}$. It indicates that the water is gradually salted during the sedimentary period of the $\mathrm{E}_{3} \mathrm{~s}^{1-2}$.

\subsection{Carbon and Oxygen Isotope Characteristics}

The carbon and oxygen isotope content of dolomite is mainly affected by the temperature and salinity of the medium. Oxygen isotope composition is mainly affected by temperature, atmospheric water dilution and evaporation. The increase of temperature and the dilution of atmospheric fresh water, the $\delta^{18} \mathrm{O} \%$ орDв value is negative; the temperature decreases, resulting in the $\delta^{18} \mathrm{O} \%$ оDB value is positive. The $\delta^{13} \mathrm{C} \%$ орв indicates the source of organic carbon in the sediment. For example, the methane formation causes the $\delta^{13} \mathrm{C} \%$ орв value to be positive, and the organic matter oxidation causes the $\delta^{13} \mathrm{C} \%$ ордв to be negative [13] [14] [15] [16].

The lowest value of $\delta^{18} \mathrm{O} \%$ ордв in the study area was $-14.9 \%$, the highest value was $-9.1 \%$, the value is negative. The lowest value of $\delta^{13} \mathrm{C} \%$ ордв is $-3.5 \%$, the highest value is $9.2 \%$, the average value is $4.05 \%$, the value is basically positive (Table 1). The range of carbon and oxygen isotope composition varies widely, indicating the different formation environments and diverse formation mechanisms of dolomite [4]. There is a significant positive correlation between $\delta^{88} \mathrm{O} \%$ pDB

Table 1. Carbon and oxygen isotope analysis results of dolomitic glutenite.

\begin{tabular}{|c|c|c|c|c|c|c|c|}
\hline Stratum & $\begin{array}{l}\text { Sample } \\
\text { number }\end{array}$ & Lithology & $\delta^{13} \mathrm{C} \%$ (PDB) & $\delta^{18} \mathrm{O} \%$ (PDB) & $\mathrm{T}\left({ }^{\circ} \mathrm{C}\right)$ & $\mathrm{Z}$ & $\begin{array}{l}\text { Diagenetic } \\
\text { environment }\end{array}$ \\
\hline \multirow{4}{*}{$\mathrm{E}_{3} \mathrm{~s}^{1}$} & 1 & $\begin{array}{l}\text { Dolomitic } \\
\text { sandstone }\end{array}$ & 2.3 & -13 & 92 & 125.5 & saltwater \\
\hline & 2 & $\begin{array}{l}\text { Dolomitic } \\
\text { glutenite }\end{array}$ & 9.2 & -13.7 & 97 & 139.3 & saltwater \\
\hline & 3 & $\begin{array}{l}\text { Dolomitic } \\
\text { glutenite }\end{array}$ & 9.2 & -13.8 & 98 & 139.3 & saltwater \\
\hline & 4 & $\begin{array}{l}\text { Dolomitic } \\
\text { glutenite }\end{array}$ & 7.6 & -12 & 84 & 136.9 & saltwater \\
\hline \multirow{3}{*}{$\mathrm{E}_{3} \mathrm{~s}^{2}$} & 5 & $\begin{array}{l}\text { Dolomitic } \\
\text { glutenite }\end{array}$ & 2.5 & -12.5 & 88 & 126.2 & saltwater \\
\hline & 6 & $\begin{array}{l}\text { Dolomitic } \\
\text { glutenite }\end{array}$ & 1.9 & -14.4 & 103 & 124 & saltwater \\
\hline & 7 & $\begin{array}{l}\text { Dolomitic } \\
\text { glutenite }\end{array}$ & -3.5 & -14.9 & 107 & 112.7 & freshwater \\
\hline \multirow{6}{*}{$\mathrm{E}_{2} \mathrm{~s}^{3}$} & 8 & $\begin{array}{l}\text { Dolomitic } \\
\text { glutenite }\end{array}$ & 4.1 & -13.3 & 94 & 129.1 & saltwater \\
\hline & 9 & $\begin{array}{l}\text { Dolomitic } \\
\text { glutenite }\end{array}$ & 3.2 & -15.2 & 109 & 126.3 & saltwater \\
\hline & 10 & Conglomerate & 6.2 & -9.1 & 64 & 135.5 & saltwater \\
\hline & 11 & Conglomerate & 6 & -9.3 & 66 & 135 & saltwater \\
\hline & 12 & Conglomerate & 1.8 & -15.2 & 109 & 123.4 & saltwater \\
\hline & 13 & Conglomerate & 2.2 & -14.5 & 103 & 124.6 & saltwater \\
\hline
\end{tabular}


and $\delta^{13} \mathrm{C} \%$ opd data (Figure 5), which indicates that the lake basin should belong to the closed lagoon basin during in $\mathrm{E}_{3} \mathrm{~s}^{1-2}$. The water circulation is poor, and the climate is arid and hot, and evaporation is dominant, which is conducive to the occurrence of dolomitization.

The salinity index $\mathrm{Z}$ and the paleotemperature $\mathrm{T}$ are good indicators for determining the salinity and temperature of do lomitization [14]. Calculated using the Keen-Weber formula $\mathrm{Z}=2.048\left(\left[\delta^{13} \mathrm{C}(\mathrm{PDB}+50)\right]+0.498\left[\delta^{18} \mathrm{O}(\mathrm{PDB}+\right.\right.$ 50)] (Table 1). Except for one sample $Z<120$, the others are greater than 120 , indicating that the dolomite in the glutenite is the product of the lagoon basin. The paleotemperature $\mathrm{T}=16.9-4.2\left(\delta^{13} \mathrm{C}-\delta^{18} \mathrm{O}\right)+0.13\left(\delta^{13} \mathrm{C}-\delta^{18} \mathrm{O}\right)^{2}, \mathrm{~T}$ is between $65^{\circ} \mathrm{C}$ and $107^{\circ} \mathrm{C}$ (Table 1), and the range of variation is large. People have shown that in the near-surface temperature of $60^{\circ} \mathrm{C}-80^{\circ} \mathrm{C}$ can form penecontemporaneous dolomite; $80^{\circ} \mathrm{C}-100^{\circ} \mathrm{C}$ to form buried dolomite; temperature > $100^{\circ} \mathrm{C}$ is conducive to form hydrothermal dolomite. The large variation of the paleotemperature in the study area represents a variety of dolomitization in this area.

Glauconite can be produced in both the lake and marine [17]. People believe that the formation environment of glauconite is similar to that of dolomite, which is a salt water environment, that is, a water depth of about 20 to $2000 \mathrm{~m}$, a water temperature of not less than $15^{\circ} \mathrm{C}$, and a weakly reducing environment of alkaline. Due to the weak hydrodynamics, the glauconite gel morphology is well preserved (Figure 6). Combined with the geochemical characteristic, it is believed that the increase of lake salinity during the sedimentary period of $\mathrm{E}_{3} \mathrm{~s}^{1-2}$, coupled with the appropriate water depth and temperature, provides a favorable environment for the formation of glauconite, thus in the eastern steep slope of the Shijiutuo bulge, the glauconite is widely developed in $\mathrm{E}_{3} \mathrm{~s}^{1-2}$.

Base on the characteristics of paleontology, the Lienardias and the baseball algals are living in a brackish water environment [18]. Arid climate indicator plants such as sporopollen, ephedra and rue also appeared in $\mathrm{E}_{3} \mathrm{~s}^{1-2}$ (Figure 7).

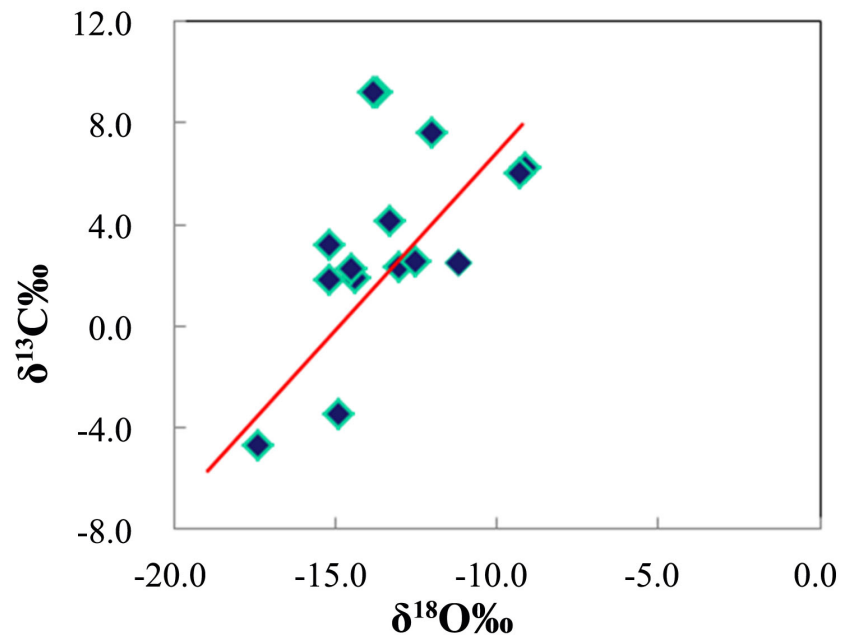

Figure 5. Carbon and oxygen isotope distribution of dolomitic glutenite. 


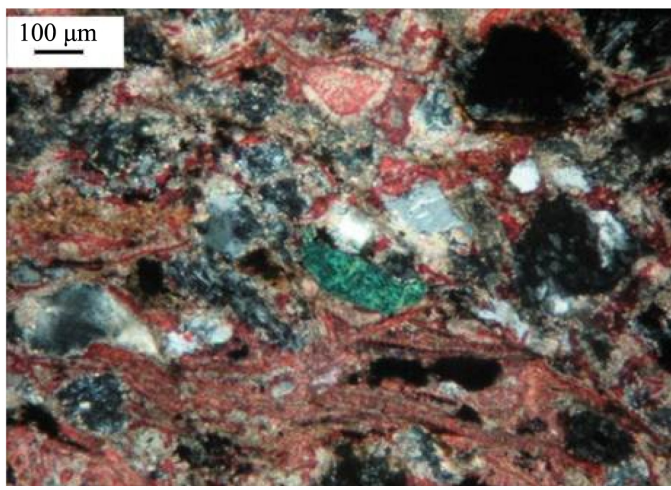

Figure 6. Glauconite (QHD29-2E-A well, $\left.\mathrm{E}_{2} \mathrm{~s}^{1-2}, 25 \mathrm{X}\right)$.

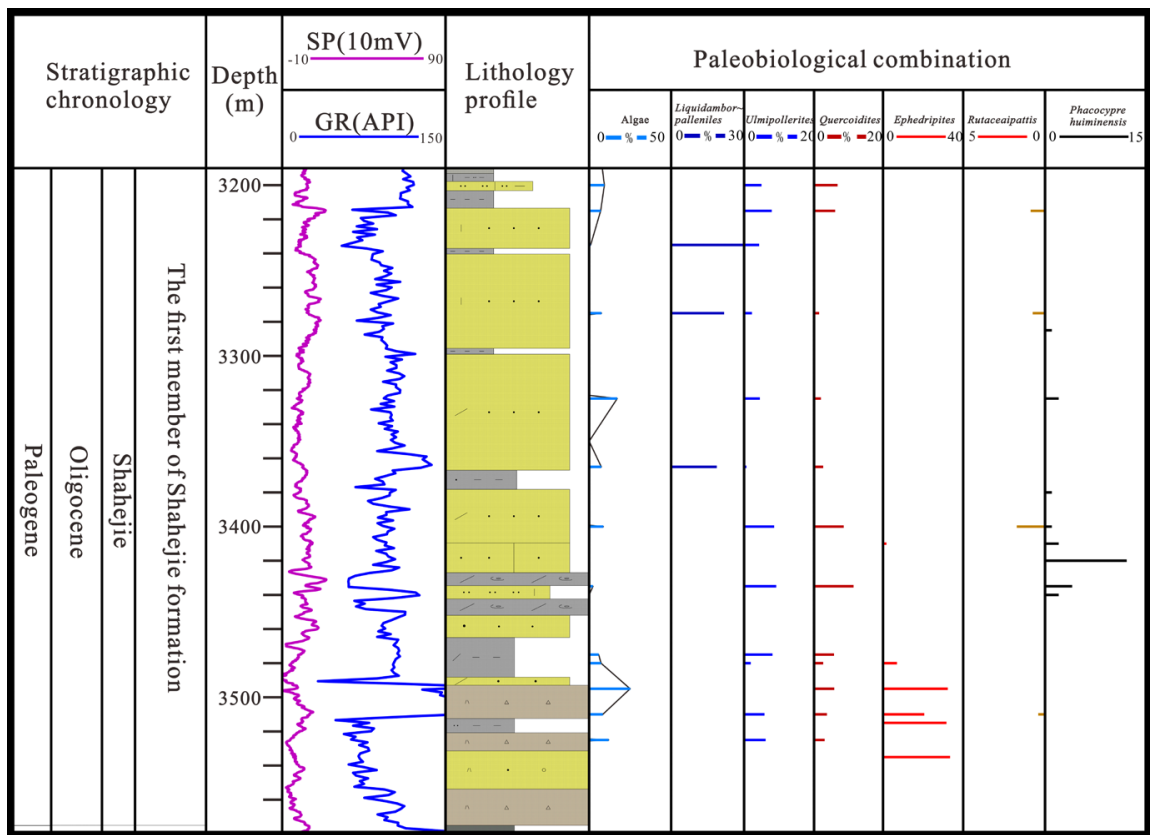

Figure 7. Paleobiological combination histogram in QHD29-2E-A well.

This is enough to prove that the sedimentary period of the $\mathrm{E}_{3} \mathrm{~s}^{1-2}$ in the study area is arid and hot, which is conducive to the occurrence of evaporation and dolomitization.

\section{The Genetic Mechanism and Genetic Mode}

The dolomitization is a very complicated problem, it is related to the sedimentary environment, the paleogeomorphology, climate and hydrology, and even involves chemical thermodynamics, kinetics, and even microbiology. The dolomitization can be formed in the penecontemporaneous period, shallow burial period, deep burial period, etc. and may also overlap each other, causing the destruction of the early structure, which makes the study of the cause and mechanism of dolomite more difficult [19] [20] [21] [22]. Based on dolomite petrology and mineralogy analysis, this paper discusses the sedimentary environment of dolomite and its genetic mechanism, and establishes the genetic model. 


\subsection{The Genetic Mechanism}

The petrology and mineralogy characteristics indicate that there are three genetic types of dolomite in $\mathrm{E}_{3} \mathrm{~s}^{1-2}$ : penecontemporaneous dolomite, buried dolomite and hydrothermal dolomite.

The QHD29-2E-A well is located in a single-break steep slope belt. The study area is located at the boundary of the large fault. The height difference between the upper and lower fault is large. Affected by the fault, the study area is a semi-occluded lake, the climate was arid and hot, and the evaporation was strong. The high salinity and rich $\mathrm{Mg}^{2+}$ brine formed by evaporation mixed with high-magnesium calcite and aragonite components in the lake basin can occur dolomitization. The dolomite in this period is penecontemporaneous dolomite, which is mainly cryptocrystalline-microcrystalline structure, accompanied by typical minerals such as gypsum (Figure 8(a)) and rock salt (Figure 8(b)), which are evidences of the occurrence of dolomitization in penecontemporaneous period.

When the reservoir is buried to a certain depth, the dehydration of clay minerals causes the $\mathrm{Mg}^{2+}$ in the high-magnesium formation migrate into the rock lead to the occurrence of dolomitization. The radius of the primary pores of the reservoir is large, which is conducive to the rapid flow of magnesium-rich fluid in the formation, further reforming the early calcite cement and other components (Figure 8(c)), and forming the idiomorphic, semi-idiomorphic powder crystal fine crystal buried dolomite. It was found by cathodoluminescence
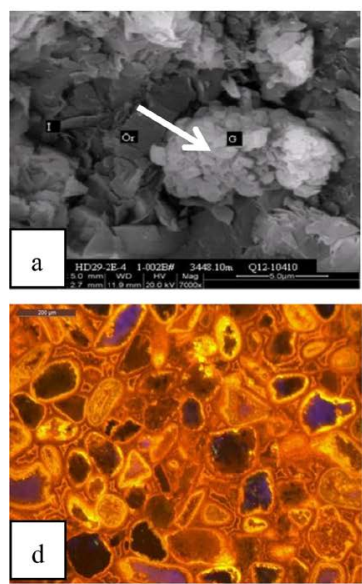
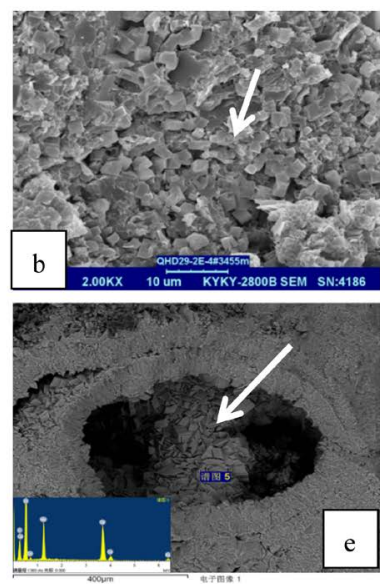

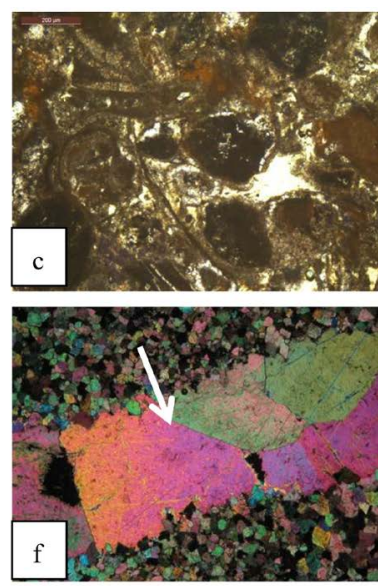

Figure 8. Mineral composition of dolomitic glutenite in QHD29-2E-A well. (a) QHD29-2E-A well, $\mathrm{E}_{3} \mathrm{~s}^{1-2}$, Filled with agglomerated gypsum in the pores, scanning electron microscope (magnification 3000). (b) QHD29-2E-A well, $\mathrm{E}_{3} \mathrm{~s}^{1-2}$, Stone salt in glutenite, scanning electron microscope (magnification 3000). (c) QHD29-2E-A well, E3s ${ }^{1-2}$, Sand dolomite, dolomitization is not complete, visible residual calcite, $12.5 \mathrm{x}(-)$. (d) QHD29-2E-B well, $\mathrm{E}_{3} \mathrm{~s}^{1-2}$, Sand dolomite, cryptocrystalline dolomitic sand grains emit orange-red light, two layers of structure, different color of luminescence, cathodoluminescence. (e) QHD29-2E-B well, $\mathrm{E}_{3} \mathrm{~s}^{1-2}$, Iron dolomite filled in the borehole (conchs) of the organism in glutenite, scanning electron microscope (magnification 3000). (f) QHD29-2E-A well, $\mathrm{E}_{3} \mathrm{~s}^{1-2}$, Crystalline iron calcite filling crack in dolomite, cross-polarized light, $25 \mathrm{x}$. 
analysis that the dolomite cement around the sand, oolith and clastic particles had a multi-layer structure and the luminescent color was significantly different (Figure 8(d)). The different of cathodoluminescence characteristics of dolomite is mainly attributed to the change of $\mathrm{Fe}^{2+}$ and $\mathrm{Mn}^{2+}$ content ratio, $\mathrm{Mn}^{2+}$ is a luminescence activator, and $\mathrm{Fe}^{2+}$ is a luminescence quencher. The study results of Richter and Zinkernagel show that $\mathrm{Fe}^{2+}$ has an effect on cathodoluminescence. With the increase of the buried depth and the increase of $\mathrm{Fe}^{2+}$ content, the cathodoluminescence color of dolomite is from orange red, dark reddish brown to dark brown and does not even emit light. Figure 8(d) shows that the outer ring layer of dark reddish brown dolomite cement should be formed by the buried dolomitization.

The occurrence of hydrothermal dolomitization is related to deep big faults. The faults can bring geothermal fluids from the mantle into the overlying strata and diafiltration into the reservoir. The hydrothermal fluid extracts magnesium ions during the process of metasomatiam, thereby forming the hydrothermal dolomite, and often coexists with a large number of hydrothermal minerals such as barite and quartz. Iron dolomite (Figure $8(e)$ ) and vein iron calcite distributed along the fissure (Figure 8(f)) can be seen in the reservoir of the study area, which provides evidence for the mechanism of hydrothermal dolomitization.

\subsection{The Genetic Mode of Dolomite}

Based on the geochemical characteristics, paleogeographic environment, genetic mechanism and sedimentary facies of dolomite, the genetic model of dolomite in dolomitic glutenite in the eastern steep slope of the Shijiutuo bulge is established (Figure 9). During the sedimentary period of the Shahejie formation, the aragonite and high-magnesium calcite deposits with mud, silt and gravel in the closed continental salt-brackish water bay. Due to the hot climate, strong evaporation, high salinity of water, penecontemporaneous dolomitization occurs in the early stage of diagenesis. Influenced by tectonic activities, deep magnesia-rich hydrothermal fluid migrates along the fault, forming buried and hydrothermal dolomite in the middle and late stage of diagenesis.

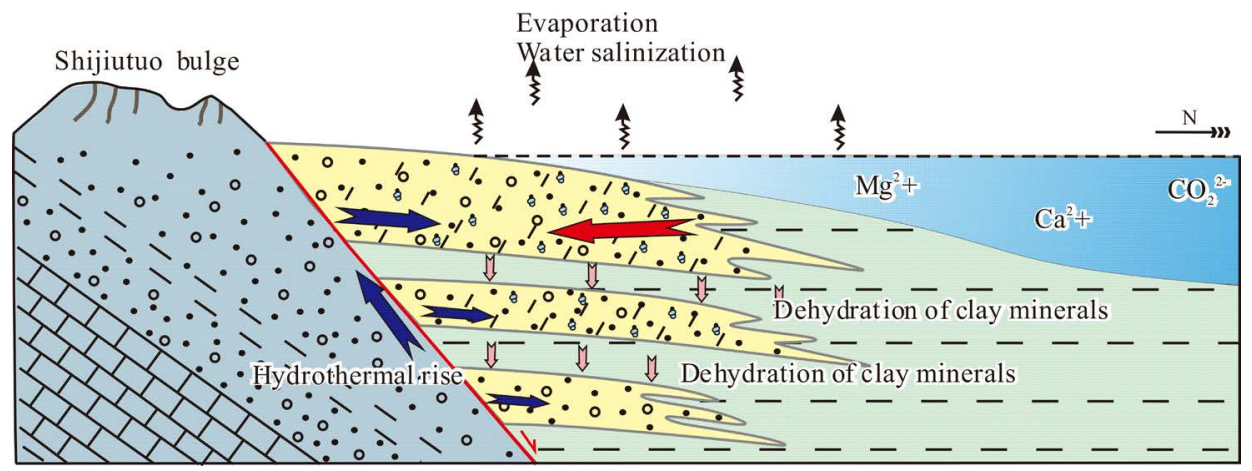

Figure 9. Schematic diagram of dolomitization in the study area. 


\section{Conclusions}

1) The dolomite in the glutenite is produced in the form of matrix, grain (sandstone, oolith), biological skeleton (conch, ostracod), clastic shell and dolomite cement. Under the microscope, three stages of dolomite cement were identified. The shape of the dolomite cement is isopachous ring, granular, horse-tooth, etc. The diagenetic environment mainly includes lake water undercurrent belt, shallowly buried undercurrent belt and deep buried hydrothermal undercurrent belt.

2) During the sedimentary period of the $\mathrm{E}_{3} \mathrm{~s}^{1-2}$, the paleogeographic environment in the eastern steep slope of the Shijiutuo bulge was closed continental salt-brackish water bay, the climate was arid and hot, and the evaporation was strong. It provides favorable conditions for the production of magnesium-rich fluid and dolomitization.

3) Three genetic models of dolomite in dolomitic glutenite are established. The first model is penecontemporaneous dolomitization. The climate was arid and hot, the aragonite and high-magnesium calcite deposited with sand and gravel. Due to the effect of evaporation, dolomitization occurred. The second model is buried dolomitization. The water from dehydration of clay minerals causes the $\mathrm{Mg}^{2+}$ in the high-magnesium formation migrating into the rock leading to the occurrence of dolomitization. The third model is hydrothermal dolomitization. Deep faults can bring geothermal fluids from the mantle into the overlying strata and diafiltration into the reservoir, and form the hydrothermal dolomite.

\section{Conflicts of Interest}

The authors declare no conflicts of interest regarding the publication of this paper.

\section{References}

[1] Zhen, R.C., Shi, J.N., Luo, A.J., et al. (2008) Comparative Study on Geochemical Behaviors of Dolomite Reservoirs in Northeast Sichuan Basin. Natural Gas Industry, 28, 16-21.

[2] Li, L., Tan, X.C., Chen, J.S., et al. (2007) Characteristics and Origin of Dolostones in Yingshan Formation, Lower and Middle Ordovician, North of Central Tarim Basin. Journal of Southwest Petroleum University (Science \& Technology Edition), 29, 34-36.

[3] Zhang, J., He, Z., Xu, H.B., et al. (2012) Petrological Characteristics and Origin of Permian Fengcheng Formation Dolomitic Rocks in Wuerhe-Fengcheng Area, Junggar Basin. Acta Sedimentologica Sinica, 30, 859-867.

[4] Shi, J., Zou, N.N., Lu X.C., et al. (2013) Geochemical Characteristics and Genetic Mechanism of Permian Dolomitic Clastic Rocks in Northwestern Junggar Basin. Acta Sedimentologica Sinica, 31, 898-904.

[5] Chen, S.Y., Li, C., Yang, Y.Q., et al. (2012) Deposition Environment of the Lacustrine Dolomite in Sha-1 Lower Submember of the Qikou Sag, Huanghua Depression. Acta Geologica Sinica, 86, 1679-1687. 
[6] Song, Z.Q., Chen, Y.F., Liu, Z.G., et al. (2013) Sedimentary Characteristics and Controls of the Carbonate Rocks during the Depositon of the First Second Members of the Shahejie Formation in the Bohai See Area. Sedimentary Geology and Tethyan Geology, 33, 5-10.

[7] Zhao, G.L., Zhao, C.L. and Ye, L.J. (2005) Sedimentary System of "Four Fans and One Channel” in the Bohai Gulf Basin and Its Significance Foe Petroleum Exploration. Journal of Geomechanics, 11, 245-258.

[8] He, Y.B. and Wang, W.G. (2006) Sedimentary Rocks and Sedimentary Facies. Petroleum Industry Press, Beijing.

[9] Peter, A., Xiao, L. and Dana, S. (2010) Ulmer-Xiaole Carbonate Petrology—Particles, Structure, Porosity and Diagenesis. Petroleum Industry Press, Beijing.

[10] Li, C. (2011) The Sline Genesis of Lacustrine Basin in the Lower Section of the First Member of Shahejie Formation in Qikou Sag. China University of Petroleum, Beijing.

[11] Liu, C., Zhang, H.L., Zhang, R.H., et al. (2010) Geochemistry Characteristic and Origin of Paleogene Dolomite in Kuqa Depression, Tarim Basin. Acta Sedimentologica Sinica, 28, 18-524.

[12] Pen, L.C. and Han, D.X. (1999) Pu Dragons Salty Continental Strontium/Barium Ratio of Lake Sediments and Its Geological Significance. Journal of China University of Mining \& Technology, 28, 50-52.

[13] He, X.B. (1997) Geochemistry of Trace Elements and Isotopes of Strontium and Application Prospects. Advances in Earth Science, 12, 15-19.

[14] Keith, M.L. and Weber, J.N. (1964) Carbon and Oxygen Isotopic Composition of Selected Limestone and Fossils. Geochimica et Cosmoehimica Acta, 28, 1787-1816. https://doi.org/10.1016/0016-7037(64)90022-5

[15] Hu, G.C. (2011) Origin of Dolomite in the Second Member of Jianlingjiang Formation of Lower Triassci. Journal of Mineralogy and Petrology, 31, 96-102.

[16] Li, Y.L., Huang, Y.J. and Wang, C.S. (2008) Geochemical Characteristics and Genetic Analysis of the Creataceous Dolomite in the Cuoqin Basin, Qinghai-Tibet Plateau. Acta Petrologica Sinica, 24, 609-615.

[17] Ge, R.Q. (2004) Occurrence and Geological Significance of Glauconite in Cenozoic Group of Jiyang Depression. Acta Sedimentologica Sinica, 22, 276-279.

[18] Chen, S.Y., Wang, L. and Li, C. (2012) The Saline Genesis of Lacustrine Basin in the Lower Section of the First Member of Shahejie Formation in Qikou Sag. Acta Petroei Sinica, 33, 40-47.

[19] Sun, Y., Zhong, J.H., Yuan, X.C. and Sun, H.L. (2008) Review and Prospect of the Study on Domestic Lacustrine Carbonate Rocks. Special Oil and Gas Reservoir, 15, 1-6.

[20] Wang, M.L., Zhou, J.G., Chen, D.X., et al. (2013) Research Advances of Dolomite Genesis Models and Discussion on Applicable Models. Marine Origin Petroleum Geology, 18, 31-40.

[21] Li, R., Jiao, Y.Q., Wu, L.Q., et al. (2008) Construct a New Model of Hydrothermal Dolomitization of an International Field of Carbonate Rocks. Geological Science and Technology Information, 27, 35-40.

[22] He, Y.L., Liu, B., Qing, S., et al. (2010) Study on the Dolomitization and Dolostone Genesis. Journal of Peking University: Natural Sciences Edition, 46, 1010-1018. 